\title{
Infectivity of Non-Lepromatous Leprosy
}

\author{
H. W. WHEATE, м.B.B.S., D.T.м. \& H. \\ Leprosy Specialist, Government Leprosarium, Chazi, Ministry of Health, Tanzania
}

While it is generally accepted that most forms of non-lepromatous leprosy may pass through a phase or phases in which the skin lesions are bacilliferous, very little is known of the frequency of such manifestations and in consequence of their importance from an epidemiological standpoint, though BROwNE (1) and (2) has drawn attention to the frequency with which the so-called 'macular dimorphous' lesions are bacilliferous.

At this leprosarium there has been a deliberate policy of concentration on the earliest possible diagnosis of the infective case at the rural dispensary, with the result that a high proportion of patients have been admitted suffering from an acute phase or reaction in the course of leprosy of a type other than lepromatous.

On the suggestion of Dr. Martinez Dominguez of w.H.o., who recently visited Chazi, the case records of patients admitted in the past 8 years have been analysed. It was found that of a total of 1,034 patients 206 , that is $20 \%$, were admitted with non-lepromatous leprosy in an acute phase. As the diagnosis was confirmed histologically in only a few patients, in order to avoid serious inaccuracies, especially those due to personal foibles in nomenclature, these 206 patients have been classified into 3 broad groups:-

(a) Tuberculoid in reaction.

(b) Indeterminate Leprosy in an acute phase, including the 'macular dimorphous' as described by Browne.

(c) Borderline and 'reactional tuberculoid', excluding all patients with lepromatous features clinically. This group is labelled for convenience 'Borderline Tuberculoid' to emphasise that it excludes 'Borderline Lepromatous'.
Bacilliferous patients occurred in all groups, as shown in the following table.

TABLE 1

\begin{tabular}{rccc}
\hline Type & $\begin{array}{c}\text { Bacteriologically } \\
\text { Positive on } \\
\text { Admission }\end{array}$ & $\begin{array}{c}\text { Bacteriologically } \\
\text { Negative on } \\
\text { Admission }\end{array}$ & Total \\
\hline Tuberculoid & & & \\
in Reaction & $38(66.6 \%)$ & $19(33.3 \%)$ & 57 \\
$\begin{array}{c}\text { Indeterminate } \\
\text { Borderline } \\
\text { Tuberculoid }\end{array}$ & $52(78.8 \%)$ & $14(11.2 \%)$ & 66 \\
\cline { 2 - 4 } Total & $165(80.0 \%)$ & $41(20.0 \%)$ & 206 \\
\cline { 2 - 4 } & & &
\end{tabular}

It is considered that the period of positivity of skin smears even under treatment is a better indication of potential infectivity than the degree of positivity on admission, this latter being liable to inaccuracy from many sources such as observer error by different microscopists at different times and differences in the positivity of the sites chosen for examination in successive patients. The following table is an analysis of these cases from this aspect.

TABLE 2

\begin{tabular}{ccccc}
\hline \multicolumn{1}{c}{$\begin{array}{c}\text { Positive at } \\
\text { Initial } \\
\text { Exam. only }\end{array}$} & $\begin{array}{c}\text { Positive } \\
\text { for } 3 \text { to } 9 \\
\text { months }\end{array}$ & $\begin{array}{c}\text { Positive for } \\
\text { 9 months } \\
\text { or more }\end{array}$ & Total \\
\hline $\begin{array}{c}\text { Tuberculoid } \\
\text { in Reaction }\end{array}$ & 20 & 16 & 2 & 38 \\
Indeterminate & 30 & $(42.7 \%)$ & $(5.2 \%)$ & \\
& $(57.7 \%)$ & $(32.7 \%)$ & $(9.6 \%)$ & 52 \\
Borderline & 26 & 28 & 21 & 75 \\
Tuberculoid & $(34.7 \%)$ & $(37.3 \%)$ & $(28.0 \%)$ & \\
\hline Total & 76 & 61 & 28 & 165 \\
& $(46.0 \%)$ & $(37.0 \%)$ & $(17.0 \%)$ & \\
\hline
\end{tabular}

Infectivity of Non-Lepromatous Leprosy 


\section{SUMMARY}

This series indicates that in this part of Africa $80 \%$ of patients with acute ('reactional') phases of non-lepromatous leprosy are potentially infective and that the period of infectivity is likely to persist for several months in over $50 \%$ of such patients. It is probable, therefore, that patients of this type are of epidemiological importance.

\section{ACKNOWLEDGEMENT}

My thanks are due to the Chief Medical Officer, Ministry of Health, Tanzania, for permission to publish this note.

\section{REFERLNCE}

BRowne, s. G. (1) Int. J. Lepr., 27 (1959), 103-109. (2) Ibid., 34 (1966), $175-178$. 